\title{
The Chk1/Cdc25A Pathway as Activators of the Cell Cycle in Neuronal Death Induced by Camptothecin
}

\author{
Yi Zhang, ${ }^{1 \star}$ Dianbo Qu, ${ }^{1 \star}$ Erick J. Morris, ${ }^{3}$ Michael J. 0’Hare, ${ }^{1}$ Steven M. Callaghan, ${ }^{1}$ Ruth S. Slack, ${ }^{1}$ Herbert M. Geller, ${ }^{2}$ \\ and David S. Park ${ }^{1}$ \\ ${ }^{1}$ Ottawa Health Research Institute, Neuroscience Group, University of Ottawa, Ottawa, Ontario, Canada, K1H 8M5, ${ }^{2}$ Division of Intramural Research, \\ National Heart Lung and Blood Institute, National Institute of Health, Bethesda, Maryland 20892, and ${ }^{3}$ Laboratory of Molecular Oncology, Massachusetts \\ General Hospital Cancer Center, Charlestown, Massachusetts 02129
}

Cell cycle regulators appear to play a paradoxical role in neuronal death. We have shown previously that cyclin-dependent kinases (CDKs), along with their downstream effectors, $\mathrm{Rb}$ (retinoblastoma) and E2F/DP1 (E2 promoter binding factor/deleted in polyposis 1), regulate neuronal death evoked by the DNA damaging agent camptothecin. However, the mechanism by which CDKs are activated in this model is unclear. The cell division cycle $25 \mathrm{~A}(\mathrm{Cdc} 25 \mathrm{~A})$ phosphatase is a critical regulator of cell cycle CDKs in proliferating cells. In cortical neurons, we presently show that expression of $\mathrm{Cdc} 25 \mathrm{~A}$ promotes death even in the absence of DNA damage. Importantly, Cdc25A activity is rapidly increased during DNA damage treatment. Inhibition of Cdc25A blocks death and reduces cyclin D1-associated kinase activity and $\mathrm{Rb}$ phosphorylation. This indicates that endogenous $\mathrm{Cdc} 25 \mathrm{~A}$ activity is important for regulation of cell cycle-mediated neuronal death. We also examined how Cdc25A activity is regulated after DNA damage. Cultured embryonic cortical neurons have a significant basal activity of checkpoint kinase 1 (Chk1), a kinase that regulates cell cycle arrest. During camptothecin treatment of neurons, this activity is rapidly downregulated with a concomitant increase in Cdc25A activity. Importantly, expression of wild-type Chk1, but not kinase-dead Chk1, inhibits the camptothecin-induced increase in Cdc25A activity. In addition, Chk1 expression also promotes survival in the presence of the DNA-damaging agent. Together, our data suggest that a Chk1/Cdc25A activity participates in activation of a cell cycle pathway-mediated death signal in neurons. These data also define how a proliferative signal may be abnormally activated in a postmitotic environment.

Key words: Chk1; Cdc25A; DNA damage; cell cycle; apoptosis; neurons

\section{Introduction}

Neuronal death is an important component in the progression of neuropathological disorders such as stroke and neurodegenerative disease (Stefanis et al., 1997; Cotman, 1998; Dirnagl et al., 1999). One important initiator of neuronal death is DNA damage, which has been implicated in conditions such as stroke (Tobita et al., 1995; Chen et al., 1997; Cui et al., 2000), Alzheimer's disease (Robison and Bradley, 1984; Gabbita et al., 1998; Lovell and Markesbery, 2001), and Parkinson's disease (Robison and Bradley, 1984; Alam et al., 1997; Jenner, 1998). Genotoxic agents/stress have also been associated with cerebellar toxicity syndrome, peripheral neuropathies, as well as significant reductions in the intelligence quotient (Wallach et al., 1992; Mansfield and Castillo, 1994; Radcliffe et al., 1994).

\footnotetext{
Received Nov. 7, 2005; accepted July 18, 2006.

This work was supported by funds from the Heart and Stroke Foundation of Ontario, Canadian Institutes of Health Research, the Center for Stroke Recovery, the Canadian Stroke Network, and the Parkinson's Research Consortium (D.S.P). We are grateful to Dr. Stephen J. Elledge (Harvard Medical School, Boston, MA) for wild-type and mutant Chk1 constructs.

*Y.Z. and D.Q. contributed equally to this work.

Correspondence should be addressed to Dr. David S. Park, Ottawa Health Research Institute, Neuroscience Group, University of Ottawa, 451 Smyth Road, Ottawa, Ontario, Canada, K1H 8M5. E-mail: dpark@uottawa.ca. DOI:10.1523/JNEUROSCI.2593-06.2006

Copyright $\odot 2006$ Society for Neuroscience $\quad$ 0270-6474/06/268819-10\$15.00/0
}

Increasing evidence indicates that one important signal in neuronal death involves the paradoxical activation of cell cycle machinery (Becker and Bonni, 2004; Greene et al., 2004; Herrup et al., 2004; Kruman et al., 2004). A growing number of reports have implicated critical cell cycle regulators, the cyclindependent kinases (CDKs), in several in vitro neuronal death paradigms, including those initiated by DNA-damaging agents (Park et al., 1996, 1998), $\beta$-amyloid toxicity (Copani et al., 1999; Giovanni et al., 1999, 2000), trophic factor deprivation (Farinelli and Greene, 1996; Park et al., 1996, 1997b), and protesomal inhibitors (Rideout et al., 2003). For example, cyclin D1-associated kinase activity (CDK4/6) is inappropriately increased in cortical neurons treated with the topoisomerase I inhibitor camptothecin (Park et al., 1998). We used this particular model to study the signaling events that are activated during genotoxic stimulus. Deregulation of cyclin D1/CDK4/6 has been reported in other death models, including $\mathrm{K}^{+}$deprivation (Padmanabhan et al., 1999) and ischemia (Osuga et al., 2000). Initial reports on the importance of CDKs in neuronal death in vitro relied on pharmacological agents. For example, flavopiridol and roscovitine block death attributable to $\mathrm{K}^{+}$withdrawal (Park et al., 1997a; Padmanabhan et al., 1999). More recently, molecular evidence implicating cell cycle CDKs has emerged. Overexpression of dominant-negative CDK4/6 or of the CDK inhibitors p16 and 
p27 can block death attributable to DNA damage (Park et al., 1998), $\beta$-amyloid (Copani et al., 1999; Giovanni et al., 1999), and proteasomal inhibitors (Rideout et al., 2003). Cyclin D1deficient neurons are also resistant to delayed hypoxic insult (Rashidian et al., 2005).

The downstream effectors of CDKs that promote neuronal death are also starting to be delineated. For example, CDKdependent $\mathrm{Rb}$ phosphorylation has been reported in a number of death paradigms, including that with the topoisomerase 1 inhibitor camptothecin. Camptothecin induces rapid pRb/p107 phosphorylation on Ser795 (Park et al., 2000) and subsequent degradation. Importantly, overexpression of $\mathrm{Rb}$ has been shown to protect against neuronal death (Park et al., 2000; Liu and Greene, 2001). Loss of the E2 promoter binding factor (E2F)/Rb repressional complexes have also been implicated in other death models (Liu and Greene, 2001; Biswas et al., 2005). E2F-1 expression evokes neuronal death, and endogenous E2F-1 mediates the death of cerebellar granule neuron (CGNs) evoked by low $\mathrm{K}^{+}$ (Hou et al., 2000; O'Hare et al., 2000). In addition, E2F-1deficient CGNs are more resistant to kainic acid-induced death (R. A. Smith et al., 2003).

These in vitro findings of the pro-death function of CDKs in neurons are highlighted by the reports that CDKs are also activated and required in in vivo models of injury. For example, inappropriate activation of CDKs have been reported in animal models of Parkinson's disease (P. D. Smith et al., 2003, 2004), stroke (Li et al., 1997; Osuga et al., 2000; Katchanov et al., 2001; Rashidian et al., 2005; Wen et al., 2005), and amyotrophic lateral sclerosis (Nguyen et al., 2003). In human postmortem analyses, aberrant cyclin and CDK expression has been reported in Alzheimer's disease brain (McShea et al., 1997; Busser et al., 1998; Herrup and Arendt, 2002; Jordan-Sciutto et al., 2002).

Although the downstream targets of CDKs in neurons are beginning to be defined, the manner by which they become activated is not well understood. In a model of cortical neuronal death induced by DNA damage, cyclin D1-associated kinase activity as well as Rb phosphorylation is detected early (Park et al., 2000). However, we also reported previously that early changes in the protein levels of numerous cell cycle regulators such as CDK4/6, cyclin D1, and casein kinase I (CKIs) (p16, p21 and p27), which might account for increased CDK activity, could not be detected (Park et al., 2000). This strongly suggested that CDKs may be regulated by a posttranslational mechanism.

The cell division cycle 25A (Cdc25A) phosphatase dephosphorylates and activates CDK4/6/cyclin D1 complexes during $\mathrm{G}_{1}$-to-S transition (Terada et al., 1995; Iavarone and Massague, 1997) in proliferating cells. It is itself negatively regulated by phosphorylation mediated by checkpoint kinase 1 (Chk1), which is involved in an S-phase checkpoint pathway responding to genotoxic stress evoked by DNA-damaging agents or irradiation (Sanchez et al., 1997; Mailand et al., 2000). However, whether Chk1 or Cdc25A play a role in responding to camptothecininduced stress within neurons is unknown. Accordingly, we explored whether this pathway may be critical in the regulation of pro-death CDK activity in neurons induced by this apoptotic agent.

\section{Materials and Methods}

Materials. NSC95397 [2,3-bis-(2-hydroxyethylsulfanyl)-1,4-naphthoquinone] was kindly provided by the Drug Synthesis and Chemistry Branch, National Cancer Institute (Bethesda, MD). Stock solutions were prepared by dissolving NSC95397 in DMSO at a concentration of 200 $\mathrm{mm}$ and were stored at $-20^{\circ} \mathrm{C}$. Immediately before treatment, the
NSC95397 stock solution was further diluted in serum-free media. Camptothecin was obtained from Sigma (St. Louis, MO).

Neuronal cultures and calcium phosphate transfection. Primary cortical neurons were derived from embryonic day 15 (E15) CD-1 mice (Charles River Laboratories, Wilmington, MA) as described previously (Xiang et al., 1996; Fortin et al., 2001) and maintained in Neurobasal media (Invitrogen, Carlsbad, CA) supplemented with B27 (Invitrogen), N2 (Invitrogen), and $0.5 \mathrm{~mm}$ glutamine (Sigma). These cultures contain $98 \%$ neurons and little contamination of other cell types (data not shown). Neurons were plated on poly-D-lysine (Sigma) -coated $35 \mathrm{~mm}$ six-well plates at a density of $2.5 \times 10^{6}$ per well. Three days after plating, cortical neurons were transiently transfected using a modified calcium phosphate precipitation protocol (Xia et al., 1996). In brief, neurons were transfected with $2 \mu \mathrm{g}$ of total plasmid DNA [ $1.5 \mu \mathrm{g}$ of plasmid DNA and $0.5 \mu \mathrm{g}$ of phosphorylated enhanced green fluorescent protein (pEGFP) as a reporter] purified using an EndoFree Plasmid Maxi kit (Qiagen, Hilden, Germany). At $24 \mathrm{~h}$ after transfection, neurons were treated with camptothecin $(10 \mu \mathrm{M})$ for $16-20 \mathrm{~h}$, were fixed in $4 \%$ paraformaldehyde (containing $0.2 \%$ picric acid in $0.1 \mathrm{M}$ phosphate buffer, $\mathrm{pH} 6.9$ ), and then stained with Hoechst $33258(0.25 \mu \mathrm{g} / \mathrm{ml})$ to assess nuclear morphology. This protocol results in $<3 \%$ transfection efficiency of plasmid DNA. Therefore, individual transfected neurons were visualized by cotransfected GFP. Survival of these neurons was assessed as either alive or dead by nuclear morphology and is expressed as ratio of live neurons to total neurons assessed. Data are expressed as mean \pm SEM.

RNA interference. To suppress the expression of Cdc25A, we designed two double-stranded short-interfering RNA (siRNA) to Cdc25A (sequences, CCGAUUCAGGUUUCUGUCUTT and GCCACUCUGAUUCUCUAGATT). The siRNA/Cdc25A duplexes along with a cyanine 3-labeled control duplex were obtained from Ambion (Austin, TX). Three days after plating, cortical neurons were transfected as described previously (Aleyasin et al., 2004) or with calcium phosphate as described above with $60 \mathrm{pmol}$ siRNA/24 well. At $24 \mathrm{~h}$ after transfection, neurons were treated with camptothecin $(10 \mu \mathrm{M})$ for various periods of time. At appropriate times, the cells were lysed and assayed for survival or Western blot analyses as described below.

Survival assay. For Figures 3, 4, and 8, survival was determined as described previously (Rukenstein et al., 1991; O'Hare et al., 2000) by incubating neurons in a buffer that selectively lyses cell membranes but not nuclear membranes and then counting the number of healthy intact nuclei. The percentage of surviving neurons is expressed relative to untreated control wells. For survival of transfected neurons (see Fig. 2), cultures were fixed and stained with the nuclear marker Hoescht. GFPexpressing neurons were counted as either alive or dead according to the appearance of Hoescht. Live neurons displayed large intact nuclei, whereas dead neurons displayed condensed and/or fragmented nuclei. Survival was expressed as the percentage of total cells that were classified as alive.

Recombinant adenovirus infection. The adenoviruses expressing wildtype (WT) or kinase-inactive/dead (DN) forms of Chk1 (kind gifts from Dr. S. J. Elledge, Harvard Medical School, Boston, MA) were engineered by using a Cre-lox adenoviral construction system as described previously (Aleyasin et al., 2004). The experiments were performed at a multiplicity of infection of 100 plaque-forming units per cell. Recombinant adenoviral vectors were added to cell suspension immediately before plating of primary neuronal cultures.

Cdc25A phosphatase assay. The phosphatase activity of Cdc25A was assayed by hydrolysis of 4-nitrophenol phosphate (pNPP) (Roche Applied Science, Indianapolis, IN) as described previously (Baratte et al., 1992) with modifications. E15 cortical neurons were treated with $10 \mu \mathrm{M}$ camptothecin for various time periods $36 \mathrm{~h}$ after plating. The cells were washed twice with cold PBS and harvested in immunoprecipitation (IP) buffer [50 mм HEPES, pH 7.5, 150 mм NaCl, 1 mm EDTA, 2.5 mм EGTA, $1 \mathrm{~mm}$ DTT, $0.1 \%$ Tween 20, and protease inhibitor cocktail (Roche)]. Protein $(500 \mu \mathrm{g})$ was incubated with $2-4 \mu \mathrm{g}$ of anti-Cdc25A antibody (Upstate Biotechnology, Lake Placid, NY) for overnight at $4^{\circ} \mathrm{C}$ and precipitated with protein A-Sepharose beads (Sigma) for $1 \mathrm{~h}$. Extracts that lacked anti-Cdc25A antibody in the immunoprecipitation step were included as an experimental control. The beads from Cdc25A immunoprecipitates was then incubated in phosphatase reaction buffer (in mм: 50 
Tris, pH 8.0, $50 \mathrm{NaCl}, 1 \mathrm{EDTA}, 1 \mathrm{DTT}$, and $1 \mathrm{pNPP}$ ) for $6-10 \mathrm{~h}$ at $37^{\circ} \mathrm{C}$. The reaction was stopped with $5 \mathrm{~N} \mathrm{NaOH}$. Cdc25A activity was calculated by measuring the absorbance of $p$-nitrophenolate at $410 \mathrm{~nm}$ and subtracting the control background value. Each point is the mean \pm SEM of data from at least three separate experiments.

Protein kinase assay. Cyclin D1-associated kinase activity or Chk1 kinase assay was performed as described previously (Matsushime et al., 1994; Park et al., 1998) with modifications. In brief, cortical neurons were treated for various times with camptothecin $(10 \mu \mathrm{M})$. The cells were washed twice with cold PBS and harvested in IP buffer as described previously (Matsushime et al., 1994). Cell lysates were then precleared by incubation with $75 \mu \mathrm{l}$ of protein A-agarose beads (Sigma) for $1 \mathrm{~h}$. One microgram of anti-cyclin D1 (Santa Cruz Biotechnology, Santa Cruz, CA) or anti-Chk1 antibody (Santa Cruz Biotechnology) (two different antibodies, one generated in rabbit FL-476 and the other from goat $\mathrm{M}-16$, were used with similar results) was then added to $300 \mu \mathrm{g}$ of cell lysate and incubated for $3 \mathrm{~h}$. As control, lysate containing no antibody was used. Protein A beads $(50 \mu \mathrm{l})$ were then added to the lysates and incubated for $1 \mathrm{~h}$. Washing and kinase assay was performed as described previously (Matsushime et al., 1994). pRb (1 $\mu$ g; Santa Cruz Biotechnology) or glutathione $S$-transferase (GST)-Cdc25A protein was used as substrate. The proteins were then resolved on a $10 \%$ SDS-polyacrylamide gel, and incorporation of $\left[\gamma_{-}{ }^{32} \mathrm{P}\right]$ ATP was analyzed by autoradiography and densitometry.

Immunofluorescence. Cortical neurons were fixed in $4 \%$ paraformaldehyde (containing $0.2 \%$ picric acid in $0.1 \mathrm{~m}$ phosphate buffer, $\mathrm{pH} 6.9$ ) for $15 \mathrm{~min}$ at room temperature and permeabilized for $20 \mathrm{~min}$ in $0.2 \%$ Triton X-100/PBS. After washing, neurons were incubated with or without anti-Cdc25A antibody (1:500; Santa Cruz Biotechnology) overnight at $4^{\circ} \mathrm{C}$. Then the cells were incubated with AlexaFluor 594 (Invitrogen) for $1 \mathrm{~h}$ at room temperature. Nuclei were stained with Hoescht 33258 $(0.25 \mu \mathrm{g} / \mathrm{ml})$ for $20 \mathrm{~min}$ at room temperature.

Western blot analysis. At $36 \mathrm{~h}$ after plating, at the indicated time points after camptothecin and/or NSC95397 treatment, cortical neurons were harvested into solubilization buffer $(0.0625 \mathrm{M}$ Tris, $2.5 \mathrm{~mm}$ EDTA, $2.5 \mathrm{~mm}$ EGTA, $10 \%$ glycerol, $2 \%$ SDS, $0.001 \%$ bromophenol blue, and $5 \%$ $\beta$-mercaptoethanol). Alternatively, immunoprecipitation was performed using antiCdc25A antibody (described above). Protein was loaded onto SDS-polyacrylamide gels and transferred to nitrocellulose membranes as described previously. Membranes were then probed with anti-Cdc25A (1:1000; Santa Cruz Biotechnology), anti-Chk1 (1:1000; Santa Cruz Biotechnology), anti-pRb (Ser795) (1:500; Cell Signaling Technology, Danvers, MA), and anti- $\beta$-actin antibody (Sigma).

Single-cell gel electrophoresis "comet assay" for DNA strand-break anal$y$ sis. DNA strand-break formation was directly determined by alkaline single-cell gel electrophoresis (SCGE) as described previously (Morris et al., 1999). Purified cultures of 1- to 2-d-old embryonic day 17 rat cerebral cortical neurons were prepared as described previously (Morris and Geller, 1996). Cells were exposed to DNA-damaging agents (or control conditions), followed by an extensive washout (three $1 \mathrm{~min}$ washes with PBS) and cell harvesting (a process lasting $\sim 10 \mathrm{~min}$ ), and were subjected to SCGE analysis. Nuclei were visualized under fluorescein epifluorescence with a $20 \times$ Zeiss (Thornwood, NY) Plan-Neofluor objective, and images were captured to disk for analysis with NIH Image version 1.59. The "tail moment" or "comet moment" (Olive and Banath, 1993) was defined ( $M_{C}$ in the equation) as the quantity of comet tail DNA (or the sum of pixels, $\Sigma P_{C}$, in the comet minus background, $b$ ) multiplied by the length of the comet tail $\left(L_{C}\right)$ or the distance from the end of the tail to the front of the comet head at the point in which the DNA began to migrate: $M_{C}=\Sigma\left(P_{C}-b\right) L_{C}$

Approximately $27-34$ neurons were analyzed per condition, and the mean \pm SEM of the comet moment was plotted for experimental conditions versus control conditions.

\section{Results}

\section{The required role of $\mathrm{Cdc} 25 \mathrm{~A}$ in neuronal death induced by DNA damage}

Camptothecin is a topoisomerase I inhibitor (L. F. Liu et al., 2000), which we have shown induces apoptotic death of cultured embryonic cortical neurons in a manner dependent on Bax and the conserved mitochondrial pathway of death (cytochrome $c$ release and activation of the apoptosome) (Enokido et al., 1996; Keramaris et al., 2000; Morris et al., 2001). Importantly, we presently show that camptothecin is a DNA-damaging agent (supplemental Fig. S1, available at www.jneurosci.org as supplemental material). Brief (10 min) treatment of cultured cortical neurons with camptothecin induces DNA strand breaks as made evident by SCGE comet-assay analyses. During SCGE analysis, individual neuronal nuclei from cells treated with camptothecin or DMSO control were agarose embedded and subjected to lysis, followed by chromatin denaturation and unwinding. As positive control, neurons were also treated with UV-C irradiation before SCGE. After ethidium bromide staining and pseudocolor image enhancement, control-treated neuronal nuclei had little DNA migration toward the anode, whereas significant comet tail formation was observed with neuronal nuclei after UV irradiation. Treatment with neurotoxic doses of camptothecin was sufficient to produce large comet tail formation in neurons, and quantification of comet tails demonstrated significant comet moment formation after camptothecin treatment. This result indicates the genotoxic nature of even short-term $(10 \mathrm{~min})$ camptothecin treatment and suggests it to be one of the earliest events induced by camptothecin treatment.

What are the consequences of such genotoxic stress? Previously, we also provided evidence that the CDK/Rb/E2F pathway is activated and required for death in this system (Park et al., $1998,2000)$. This activation occurs quite early in the apoptotic cascade (2-4 h) and temporally before detectable caspase activity, which is observed 6-8 h after initiation of camptothecin treatment (Stefanis et al., 1999). We also demonstrated that cell cycle CDK signaling is activated independently of p53, a tumor suppressor transcription factor required for death in this paradigm (Morris et al., 2001). Together, cell cycle CDKs and downstream elements of the p53 pathway are both required for Bax activation (Morris et al., 2001).

The mechanism underlying CDK activation in neuronal death was unclear. Because we could not previously detect gross changes in protein levels of CDKs or their regulators, which might account for increased CDK activity during DNA damage (Park et al., 2000), we focused on potential regulators of posttranslational signaling. The important role of Cdc25A in the regulation of CDK4/6/cyclin D1 during cell cycle progression led us to examine its potential role in neuronal death after DNA damage. Accordingly, we first determined whether Cdc25A activity might be increased after DNA damage. To do this, we exposed embryonic cortical cultures to camptothecin and then at varying times harvested the neurons, immunoprecipitated Cdc25A, and performed a phosphatase assay using pNPP as substrate. As shown in Figure $1 A$, there was an approximate fourfold increase in Cdc25A phosphatase activity $2 \mathrm{~h}$ after camptothecin treatment compared with the normal controls. This indicates that Cdc25A activity increases early, at similar times that we reported for $\mathrm{Rb}$ phosphorylation in this paradigm (Park et al., 2000). Addition of the Cdc25A inhibitor NSC95397 $(2 \mu \mathrm{M})$ in the assay mixture completely abolished all detectable phosphatase activity, suggesting that the IP phosphatase assay used was indeed targeted toward Cdc25A activity (data not shown). As shown in Figure $1, B$ and $C$, we confirmed that Cdc25A can be detected in cortical neurons by both IP/Western blot analyses or immunofluorescence.

The above evidence indicates that $\mathrm{Cdc} 25 \mathrm{~A}$ activity is increased during exposure to a DNA-damaging agent. We next examined the function of Cdc25A as it relates to neuronal death in this 
A.

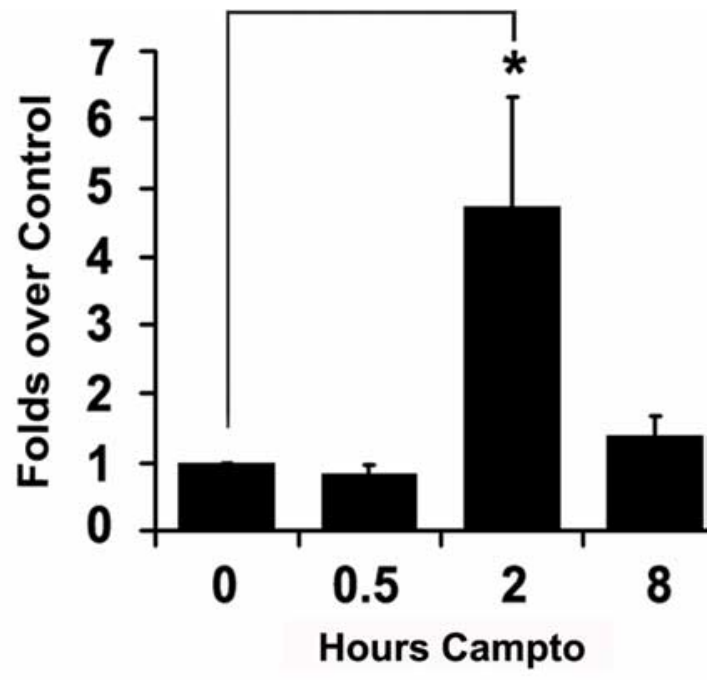

B.

C.

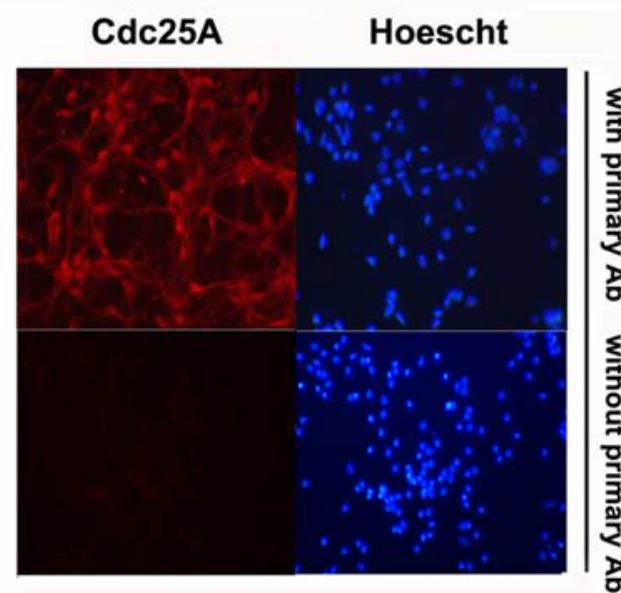

Figure 1. Cdc25A phosphatase activity is increased in cortical neurons treated with camptothecin. $A$, Cdc25A phosphatase was immunoprecipitated from $500 \mu \mathrm{g}$ of whole-cell lysate of cortical neurons treated for various times with camptothecin (Campto) and subjected to phosphatase assay using pNPP as substrate. Phosphatase activity was assayed by liberation of the pNPP cleavage product quantitated at $\mathrm{OD}_{410}$ by spectrophotometry. Significance comparisons with time 0 control, ${ }^{*} p<0.05$. Data represent the mean \pm SEM from seven independent experiments. $\boldsymbol{B}$, A parallel IP/Western blot was performed to demonstrate pull-down of Cdc25A. IgG control refers to a control IP performed with nonspecific IgG control antibody. A crossreactive $\lg \mathrm{G}$ band is also visible after Western blot analyses. C, Neurons were fixed and immunostained for Cdc25A, and nuclei were stained with Hoescht. Culture without primary antibody (Ab) incubation was provided as a control.

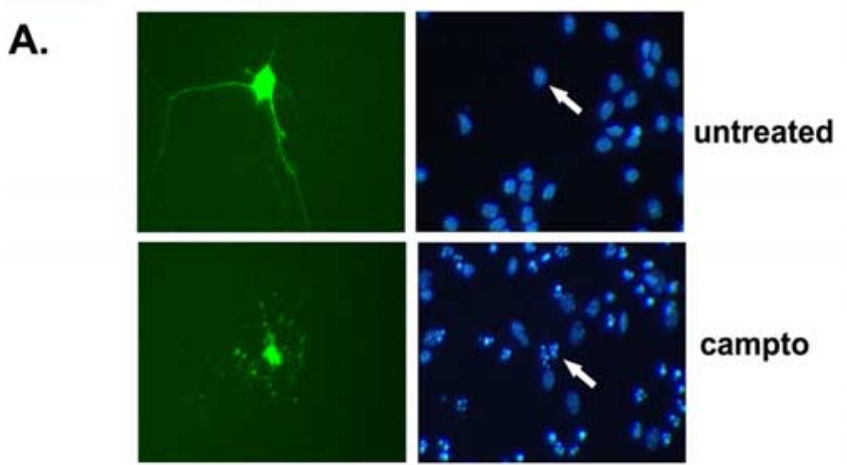

B.

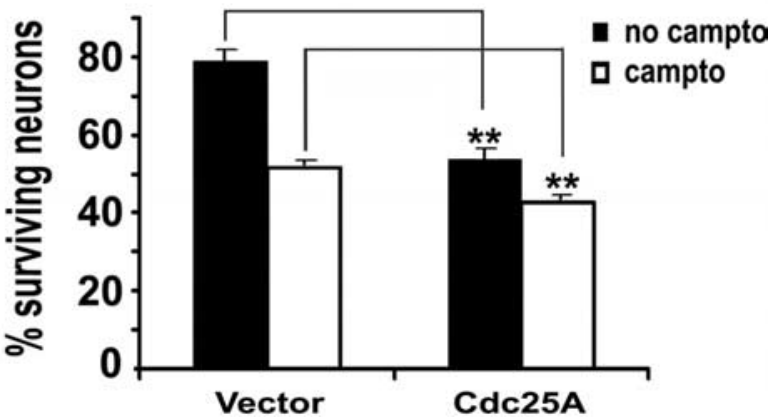

Figure 2. Cdc25A promotes neuronal death in response to DNA damage. Cultured cortical neurons were cotransfected with pEGFP and the indicated constructs. At $24 \mathrm{~h}$ after transfection, cells were exposed to camptothecin (campto) $(10 \mu \mathrm{m})$ for $16-20 \mathrm{~h}$, fixed, and stained with Hoechst $33258(0.25 \mu \mathrm{g} / \mathrm{ml})$. A, Photomicrographs of alive or dead cortical neurons under green fluorescence, showing GFP-transfected neurons and Hoechst-stained nuclei. $\boldsymbol{B}$, Expression of $\mathrm{Cdc} 25 \mathrm{~A}$ using a plasmid construct induces death of primary cultured cortical neurons treated with camptothecin. Significance comparisons with respective vector untreated or camptothecin-treated controls, ${ }^{* *} p<0.01$. Data represent the mean \pm SEM from three independent experiments.

system. We first targeted plasmid expressing Cdc25A or empty vector control to neurons by calcium phosphate-mediated transfection. A GFP-expressing plasmid was also cotransfected as a marker for positively targeted neurons. Transfected cultures were untreated or exposed to camptothecin. Cultures were then fixed and stained with Hoechst. GFP-positive neurons were scored for survival by evaluating nuclear integrity. Dead cells displayed fragmented and/or condensed nuclei. As shown in Figure 2, expression of Cdc25A alone, even without camptothecin treatment, is sufficient to induce death of cultured cortical neurons (53\%). In contrast, GFP expression alone had only minimal background toxic effects ( $\sim 80 \%$ survival). During camptothecin treatment, Cdc25A-expressing neurons showed an additional increase in death. However, this death was only marginally increased over death observed in vector-expressing control neurons. This evidence indicates that overexpression of $\mathrm{Cdc} 25 \mathrm{~A}$ is sufficient to induce death. Overexpression of Cdc25A only slightly enhances additional death with camptothecin treatment, suggesting that the Cdc25A pathway is already mostly activated with camptothecin exposure.

The above expression experiments do not indicate whether endogenous Cdc25A is necessary for DNA damage-induced death. Therefore, we next determined whether Cdc25A might be necessary for death induced by camptothecin. To test this, we first cultured cortical neurons in the presence of varying doses of the Cdc25A inhibitor NSC95397, with or without camptothecin 
A.

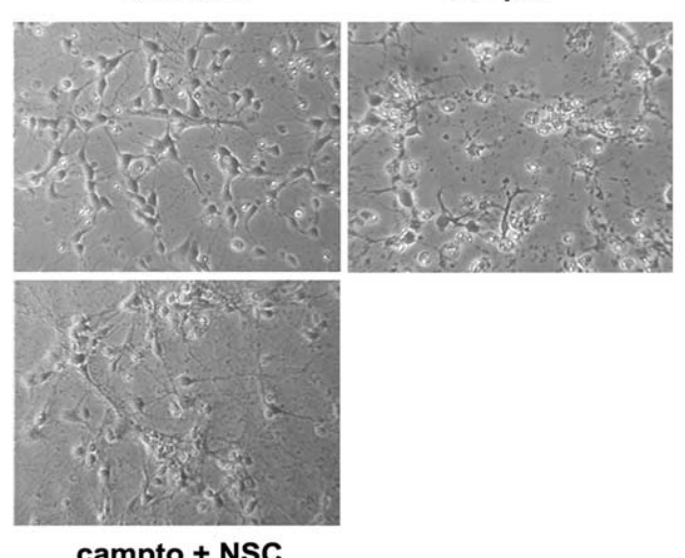

campto + NSC

B.

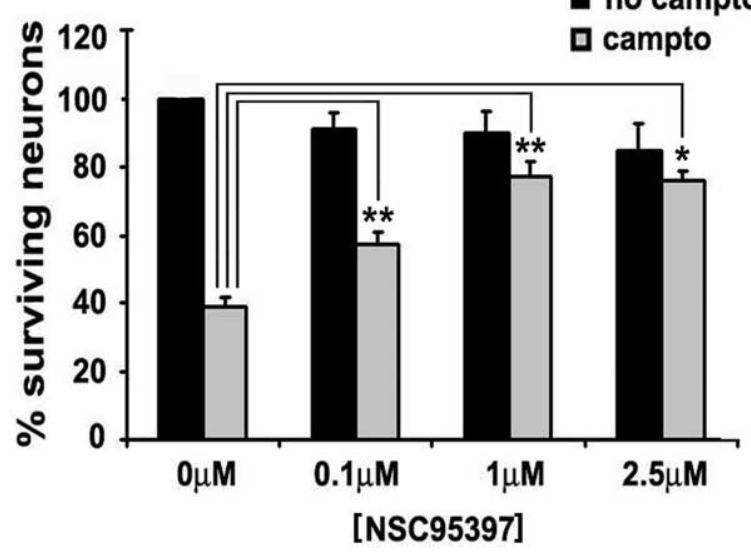

Figure 3. Cdc25A inhibition with NSC95397 protects cortical neurons from camptothecininduced neuronal death. At $36 \mathrm{~h}$ after plating, cortical neurons were treated with camptothecin $(10 \mu \mathrm{M})$ alone or cotreated with NSC95397. A, Phase micrographs of neuronal cultures not treated, treated with camptothecin (campto) $(10 \mu \mathrm{m})$ alone, and cotreated with NSC95397 (NSC) $(1 \mu \mathrm{M})$ for $12 \mathrm{~h}$. B. Survival assay of camptothecin-induced death of cortical neurons cotreated with NSC95397 at the indicated concentrations. Cells were lysed and intact nuclei were counted according to the method outlined in Materials and Methods. Significance comparisons between untreated and camptothecin treatment at each NSC concentration, ${ }^{*} p<$ $0.05,{ }^{* *} p<0.01$. Data represent the mean \pm SEM from at least three independent experiments.

treatment. NSC95397 has been reported to be a small-molecule Cdc25 dual-specificity phosphatase inhibitor, $>120$-fold more selective for Cdc25A than vaccinia H1-related dual-specificity phosphatase or protein tyrosine phosphatase $1 \mathrm{~b}$ (Lazo et al., 2002). As shown in Figure 3, the inhibitor by itself did not have any significant effect on background survival, whereas cotreatment of NSC95397 protects cortical neurons from camptothecin-induced neuronal death. Protection by this drug started at $0.1 \mu \mathrm{M}$ and was maximal at $1 \mu \mathrm{M}$.

Although NSC95397 is most selective for Cdc25A, it could also block other $\mathrm{Cdc} 25$ isoforms at slightly higher concentrations (Lazo et al., 2002). Because of this and other potential general specificity issues related to pharmacological inhibitors, we next investigated the functional importance of $\mathrm{Cdc} 25 \mathrm{~A}$ using a knockdown approach. Cortical neurons were transfected with siRNA oligonucleotides as described in Materials and Methods and treated with camptothecin for the indicated times. As shown in Figure 4, two separate Cdc25A-specific siRNA oligonucleotide but not a control siRNA resulted in significant protection from camptothecin ( $\sim 20 \%$ survival with control siRNA vs $>40 \%$ with

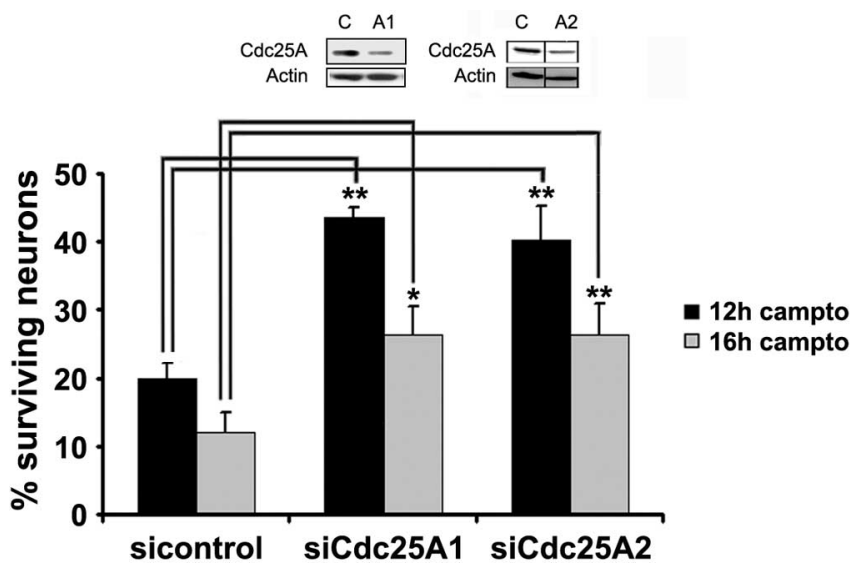

Figure 4. Cdc25A siRNA protects cortical neurons from death evoked by camptothecin. Cortical neurons were transfected with a control siRNA (sicontrol) or two separate Cdc25A siRNA oligonucleotides (siCdc25A1, siCdc25A2) as indicated for $48 \mathrm{~h}$ and then treated with camptothecin (campto) for 12 and $16 \mathrm{~h}$ also as indicated. Neurons were lysed and numbers of surviving cells were assessed. Data represent means \pm SEM of three experiments. Significance comparisons with untreated or camptothecin-treated control siRNA. ${ }^{*} p<0.05,{ }^{* *} p<0.01$. Insets at top show Western blot analyses, showing downregulation of $\mathrm{Cdc} 25 \mathrm{~A}$ in cells treated with siCdc25A1 (A1) or siCdc25A2 (A2) compared with control siRNA (C).

Cdc25A knockdown). Importantly, the Cdc25A siRNA constructs but not the control siRNA reduced protein level of Cdc25A (Fig. 4). This finding is consistent with our observations with Cdc25A overexpression and pharmacological inhibition and supports a proapoptotic role for Cdc25A activation in DNA damage. Together, these data suggest that Cdc25A is both necessary and sufficient for cortical neuron death induced by DNA damage.

Cdc25A inhibition/knockdown and effects on CDK activity Previously, we have shown that cyclin D1-associated kinase activity is increased after camptothecin treatment at an early time point similar to that presently observed with Cdc25A activation (Park et al., 1998). Cyclin D1/CDK4 complexes are known to regulate proliferation in dividing cells by phosphorylating $\mathrm{Rb}$ (Park et al., 1998). In neurons, DNA damage also results in $\mathrm{Rb}$ phosphorylation at Ser795, and this phosphorylation is dependent on CDK activity (Park et al., 2000). Rb also appears to be essential as a survival factor in this paradigm because expression of a mutant $\mathrm{Rb}$ that cannot be efficiently phosphorylated by CDKs is protective (Park et al., 2000). Accordingly, we examined whether Cdc25A might act as an upstream regulator of the $\mathrm{CDK} / \mathrm{Rb}$ pathway. We first tested whether cyclin D1-associated kinase activity might be affected by Cdc25A inhibition using the NSC95397 inhibitor. As shown in Figure 5, $A$ and $B$, treatment with camptothecin resulted in activation of cyclin D1-associated activity, consistent with our previous reports. Importantly, cotreatment with the pharmacological Cdc25A inhibitor resulted in reduction of this activity (Fig. $5 A, B$ ). It also reduced loss of tyrosine phosphorylation of cyclin D-containing complexes normally observed during camptothecin treatment (supplemental Fig. S2, available at www.jneurosci.org as supplemental material).

Consistent with the observation of reduced cyclin D-associated kinase activity, we also observed that treatment with the NSC95397 inhibitor (Fig. 5C,D) reduced Ser795-Rb phosphorylation. Rb phosphorylation was detected by Western blot analyses using a Ser795 phosphoepitope $\mathrm{Rb}$ antibody. $\mathrm{Rb}$ phosphorylation was maximal at $\sim 2-4 \mathrm{~h}$, the same time at which 


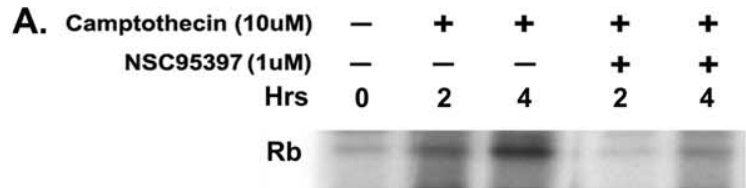

B.
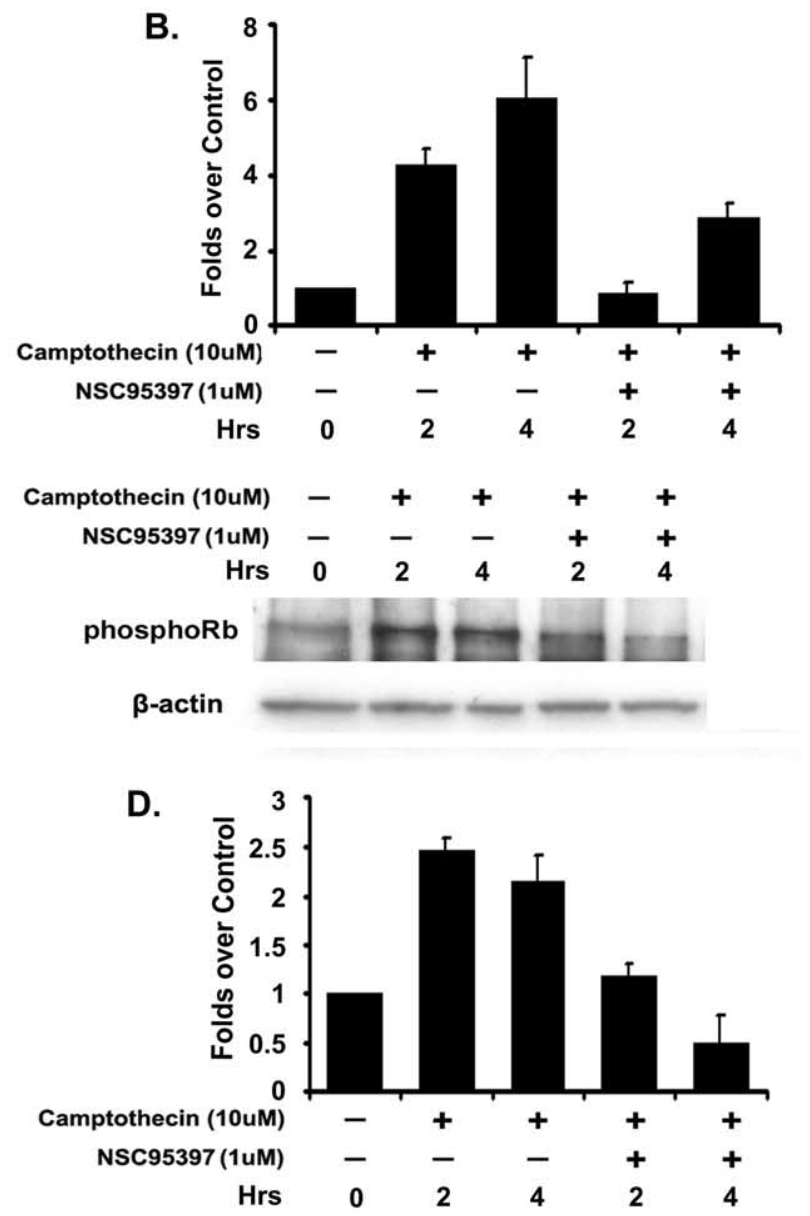

E.

$\begin{array}{llllllll}\begin{array}{c}\text { control } \\ \text { siCdc25A }\end{array} & + & + & - & - & + & + & + \\ \text { hrs campto } & 0 & 2 & 4 & 0 & 2 & 4 \\ \text { phosphoRb } & - & & & & & & \end{array}$

Figure 5. Inhibition of $\mathrm{Cd} 25$ phosphatase activity attenuates camptothecin-evoked cyclin D1-associated kinase activity and pRb phosphorylation at Ser795. A, NSC95397 decreases camptothecin-induced cyclin D1-associated kinase activity in cortical neurons. $\boldsymbol{B}$, Densitometric analysis of cyclin D1-assciated kinase activity. The kinase activity was quantified by measuring the incorporation of ${ }^{32} \mathrm{P}$ onto $\mathrm{pRb}$ substrate and subtracting the control background value. Data are the mean \pm SEM and are expressed relative to the initial amount of phosphorylated $p R b$ at time 0. C, NSC95397 (1 $\mu \mathrm{M})$ attenuates the camptothecin-evoked increase in phosphorylation of $\mathrm{Rb}-\mathrm{Ser} 795$. Western blotting analysis was performed using anti-pRb-Ser795 antibody. Actin is provided as loading control. $\boldsymbol{D}$, Densitometric analysis of Western immunoblots. Data are the mean \pm SEM and are expressed relative to the initial amount of phosphorylated $p R b$ at time 0. E, Cdc25A siRNA (sicdc25A) attenuates the camptothecin (campto)-evoked increase in phosphorylation of Rb-Ser795. Actin is provided as loading control. Similar results were observed in two separate experiments.

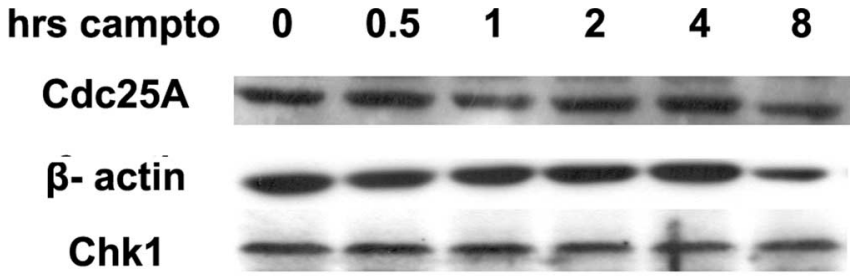

\section{$\beta$ - actin}

Figure 6. Cdc25A and Chk1 protein levels do not change significantly in response to DNA damage. Western blot showing relative Cdc25A and Chk1 levels from the whole-cell lysates of cortical neurons after camptothecin (campto) $(10 \mu \mathrm{m})$ treatment for the indicated times. Cultured cortical neurons were treated with camptothecin $(10 \mu \mathrm{m})$ for various times $36 \mathrm{~h}$ after plating, whole-cell lysates were harvested, and Western blot analysis was performed according to standard procedure. Actin is provided as loading controls.

maximal Cdc25A activity is observed (Fig. 1A). Importantly, similar results in reduction of $\mathrm{Rb}$ phosphorylation were observed with siRNA treatment against Cdc25A (Fig. 5E).

Role of Chk1 in camptothecin-induced death

The above results indicate that Cdc25A activity is increased after DNA damage and it regulates cyclin $\mathrm{D}$-associated kinase activity. However, when we examined for levels of total cellular Cdc25A by Western blot analyses with various times of camptothecin treatment, there did not appear to be any significant/robust early change in protein levels that could account for the increased activity (Fig. 6). In fact, Cdc25A levels actually decreased, although fairly late, at $8 \mathrm{~h}$. A similar lack of induction of Cdc25A was also observed with treatment with another genotoxic agent, etoposide (supplemental Fig. S3, available at www.jneurosci.org as supplemental material). Chk1 is an important regulator of Cdc25A after DNA damage, which is thought to modify Cdc25 through several mechanisms, including sequestration with 14-3-3, in addition to regulation of stability (Mailand et al., 2000). Accordingly, we next examined whether this checkpoint kinase acts as a possible upstream regulator of Cdc25A in this death model. First, we tested whether camptothecin can alter Chk1 kinase activity. As shown in Figure 7, there was a consistent and readily detectable basal level of Chk1 activity as determined by IP pull-down of Chk1 from untreated control neuronal cultures and in vitro kinase assay using GST-Cdc25A as substrate. Interestingly, camptothecin treatment led to a rapid decrease in Chk1 kinase activity to almost undetectable levels. Total levels of Chk1 itself did not change during the course of camptothecin treatment as determined by Western blot analyses (Fig. 6). This indicates that the downregulation of Chk1 activity is likely attributable to a posttranslational event.

We next determined whether loss of Chk1 activity might be functionally relevant for death after camptothecin treatment and also affect Cdc25A activation. To perform the necessary biochemical analyses of the phosphatase assay, we could not rely on transfection delivery techniques, which are extremely inefficient for plasmid DNA. Accordingly, we used recombinant adenovirus, which we have shown previously can efficiently infect neurons (O'Hare et al., 2000). We generated adenovirus expressing either WT-Chk1 or DN-Chk1 mutant.

As shown in Figure $8 \mathrm{~A}$, we first determined the effects of Chk1 on survival. Infection of cultures with adenovirus containing WT-Chk1, but not control or DN-Chk1, significantly improved survival after DNA damage. Similar results showing protection 
A.
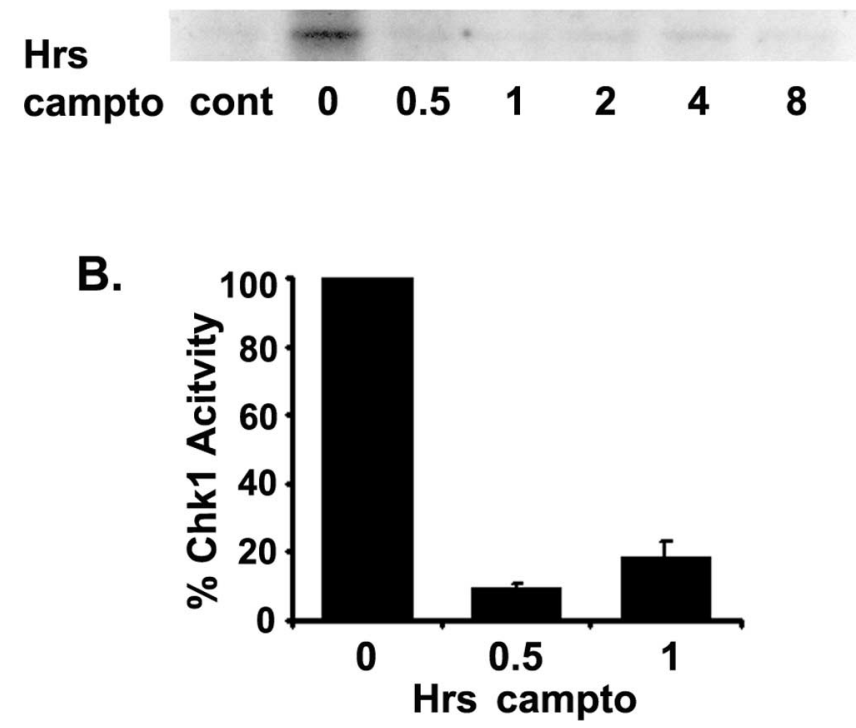

Figure 7. Chk 1 kinase activity is rapidly decreased in response to DNA damage. Chk1 activity was calculated by measuring the incorporation of ${ }^{32} \mathrm{P}$ onto GST-Cdc25A substrate and subtracting the control (cont) background value. The kinase activity from three independent experiments were analyzed by densitometry. $A$, An example of autoradiogram showing the incorporation of ${ }^{32} \mathrm{P}$ into $\mathrm{Cdc} 25 \mathrm{~A}$. campto, Camptothecin. $\boldsymbol{B}$, Autoradiograms were quantified by densitometry. Data represent the mean \pm SEM from three independent experiments.

with WT-Chk1 was also observed with transient calcium phosphate-mediated transfection of WT-Chk1 (data not shown). Together, these data indicate that endogenous Chk1 may be important for neuronal survival.

To test the hypothesis that Chk1 modulates Cdc25A activity in the camptothecin DNA damage paradigm, we examined whether/how WT-Chk1 or DN-Chk1 might affect Cdc25A activity. After infection with control, WT, or kinase-deficient virus, we exposed neuronal cultures to camptothecin and then assayed for Cdc25A activity as described above. Consistent with previous results, Cdc25A activity was increased in camptothecin-treated neurons infected with control virus. Background Cdc25A activity appeared to be slightly higher with virus treatment, and therefore total induction of Cdc25A activity was slightly less than observed in Figure $1 A$. Importantly, WT-Chk1 expression reduced basal and camptothecin-induced Cdc25A activity. Interestingly, expression of DN-Chk1 had the opposite effect from WT-Chk1, in that both background and induced Cdc25A activity were increased when compared with control virus treatment (Fig. $8 B$ ). By itself, however, DN-Chk1 expression did not significantly affect death (Fig. 8A), suggesting that the magnitude of basal Cdc25A activation induced by expression of DN-Chk1 is not sufficient on its own to promote rapid death. Together, these results suggest that Chk1 may participate in the regulation of Cdc25A. This, in turn, perhaps with other signaling events, increases cyclin D1-associated kinase activity and consequent Rb phosphorylation and inactivation.

\section{Discussion}

Reactivation of cell cycle has been shown to be a common and required event in various models of neuronal death and neurodegeneration, yet little is known regarding the mechanisms that allow for this cell cycle reactivation to occur. The results presented here address this important issue. The preceding data sug- gest that, during death induced by camptothecin, cell cycle reactivation is promoted by an increase in Cdc25A activity that, in turn, is regulated, at least in part, through a decrease in Chk1 activity.

DNA damage during $G_{1}$ or $S$ phase results in cell cycle arrest brought about by Chk1-mediated deactivation of the Cdc25A phosphatase (Mailand et al., 2000). However, we found that, in postmitotic neurons, basal Chk1 activity is normally high and Cdc25A activity was low. In response to camptothecin, Chk1 is suppressed and Cdc25A is activated, allowing for activation of downstream cell cycle regulatory events such as activation of cyclin D1-associated kinase activity and pRb phosphorylation.

\section{Chk1/Cdc25A activity in neurons}

Neurons are postmitotic cells that have terminally differentiated and exited the cell cycle. Nevertheless, numerous cell cycle proteins have been detected in cultured neurons, including CDK-1, CDK-2, CDK-4, and CDK-6 (Park et al., 2000; Konishi and Bonni, 2003; Sumrejkanchanakij et al., 2003), cyclin A, E, and D (Copani et al., 1999; Park et al., 2000; Sumrejkanchanakij et al., 2003), the CKIs p16, p21, and p27 (Park et al., 2000), E2F1 (O'Hare et al., 2000; Trinh et al., 2001), pRb (Park et al., 2000; Trinh et al., 2001), and Cdc25A (Kruman et al., 2004). Although the presence of cell cycle inhibitory proteins may be necessary to maintain the differentiated state (Zindy et al., 1999; Chen et al., 2003), the function of cell cycle-promoting proteins in postmitotic neurons is much less clear. Because neurons are not cycling, these cell cycle-promoting proteins, particularly cyclin D1/ CDK4, must be maintained in an inactive state. One mechanism by which quiescent somatic cells inactivate CDK4 is through tyrosine phosphorylation, and, to reinitiate cycling, these cells require Cdc25A-mediated tyrosine dephosphorylation. We found that both Cdc25A and Chk1 are normal constituents of embryonic brain neurons, each with detectable basal levels of activity. Interestingly, under normal conditions, the basal level of Chk1 activity in postmitotic neurons is relatively high. We suggest that this level of Chk1 activity maintains Cdc25A in a relatively low state of activation. This also suggests that the quiescence of cell cycle machinery in postmitotic neurons may result, at least in part, from the suppression of Cdc25A by Chk1. The presence of Chk1/Cdc25A in quiescent neurons led us to examine the potential function of these two proteins in a pathological context of DNA damage. Our results indicate that genotoxic stress, such as with the DNA-damaging agent camptothecin, induces Chk1 inactivation, Cdc25A activation, and subsequent cell cycle activation in postmitotic neurons.

The mechanism by which Chk1 regulates Cdc25 in our present death model is not defined. Chk1 is reported to regulate Cdc25 through multiple mechanisms, including regulation of stability, sequestration and inactivation with 14-3-3, as well a prevention of interaction with cyclin complexes (Lam and Rosen, 2004). Although we cannot rule out subtle changes in Cdc25A stability/levels, our results suggest that other mechanisms may be regulating the majority of $\mathrm{Cdc} 25 \mathrm{~A}$ activity. This contrasts with other death models that have shown increased Cdc25A levels (Kruman et al., 2004), suggesting that there may be multiple pathways of Cdc25A regulation that may or may not relate to Chk1. In addition, whereas loss of Chk1 activity is sustained, Cdc25A activity is only transiently increased. Therefore, caution must be maintained in interpreting a direct relationship between Chk1 and Cdc25A. However, this could be attributable to the fact that multiple factors regulate Cdc25. For example, Pim1 (proviral integration site 1 ) has been shown to also modify Cdc25 activity 
(Mochizuki et al., 1999). The transient nature of Cdc25A activation may be attributable to compensatory pathways that try to limit cell cycle activation in neurons. The nature of these signals, however is presently unknown.

It is also important to point out that, although the present study has focused on the role of a Chk1/Cdc25A/cyclin $\mathrm{D} / \mathrm{CDK} 4$ pathway, the potential role of Cdc25B and Cdc25C, as well as other cell cycle CDK members, is not characterized. We have shown previously that Cdk2 does not appear to functionally participate in DNA damage-induced death (Park et al., 1998). However, the role of Cdk1 (Cdc2) in this model is unknown. Cdk1 has been associated with other death models, including $\mathrm{K}^{+}$deprivation-induced death of cerebellar granule neurons (Konish and Bonni, 2003). An involvement of Cdk1 makes the study of other Cdc25 members particularly relevant because they are known to regulate later stage cell cycle CDK activity (Gautier et al., 1991). It will be interesting to investigate any roles of these signals in neuronal death in future studies.

Finally, the data in the present study are generated from cultured neurons from embryonic brain. These neurons have just turned postmitotic and have not had the opportunity to completely downregulate their cell cycle machinery. It is unclear, therefore, whether the Chk1/Cdc25A pathway might also be relevant in mature adult neurons, under normal conditions and after injury. In adult animals, relatively little cell cycle components are detected. This suggests that an active Chk1 pathway may be unnecessary to deactivate the cell cycle machinery. Other pathways or mechanisms in addition to Chk1/Cdc25A may also be important in regulating cell cycle activation in neurons after DNA damage. After injury in numerous adult situations, however, active upregulation of components such as cyclin D1 have been reported. Clearly, this upregulation is likely important for activation of cell cycle machinery in the adult. In addition, it has been reported that nuclear translocation of cyclin D1 is also increased in dying neurons (Sumrejkanchanakij et al., 2003). It is not yet clear how increased nuclear localization of cyclin D1 itself would produce an increase in total cellular cyclin D1-associated kinase activity, but it is possible that translocation occurs along with dissociation from a CKI. Whether the Chk1/Cdc25A pathway would be required in this circumstance is unclear. However, it may be that inhibitory modifications are required to be removed after active resynthesis. Intriguingly, in support of a role for Cdc25 in adult neurons, it has been reported that Cdc25A and Cdc25B activation have been found in neurons of Alzheimer's disease patients (Ding et al., 2000; Vincent et al., 2001)

\section{Chk1 versus Chk2}

Although activation of the cyclin D/CDK $4 / 6 / \mathrm{pRb}$ cell cycle pathway is required for camptothecin-induced neuronal death, it is not the only required pathway. p53 activity is also required for neuronal death caused by this DNA-damaging agent. The cell cycle and p53 pathways are activated independently (Morris et al., 2001), yet activation of both is required for Bax-mediated cytochrome $c$ release and activation of the mitochondrial death pathway. Under select circumstances, p53 activation has been shown to rely on an ataxia telangiectasia mutated protein (ATM)/ Chk2 pathway. Similar to Chk1, Chk2 kinase activity is increased after DNA damage induced by a variety of stress in dividing cells. Functionally, Chk2 can activate both apoptosis (via p53 and E2F1) and cell cycle checkpoint (via Cdc25A and Cdc25C) pathways. However, in the model of DNA damage in cortical neurons, identical to that described in this paper, p53 activation is dependent on ATM but completely independent of Chk2. ATMdeficient neurons show no activation of p53 and are significantly protected against camptothecin toxicity (Keramaris et al., 2003). Chk2-deficient neurons, conversely, show normal p53 activation and no difference in survival compared with wild-type neurons (Keramaris et al., 2003). Importantly, because Chk2 deficiency does not alter neuronal survival after camptothecin, Chk2 is unlikely to be involved in Cdc25A modulation. The relative importance of Chk1 and not Chk2 in neuronal death is paralleled in the developmental requirements between Chk1 and Chk2. Whereas Chk2 knock-out mice are viable (Hirao et al., 2002; Takai et al., 2002), loss of Chk1 results in early embryonic lethality (Q. Liu et al., 2000; Takai et al., 2000). This suggests that, although there may be some overlap in Chk1 and Chk2 function, there appears to be distinct properties of the two family members with respect to DNA damage in cortical neurons.

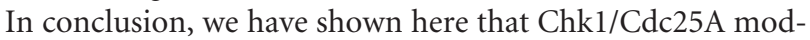
ulate cell cycle activation in neurons exposed to camptothecin. Our data provide a plausible mechanism by which cell cycle CDKs are activated in neurons after treatment with this DNAdamaging agent. Given the reported activation of cell cycle regulators in a wide variety of neuropathological states, Cdc25A may be a novel therapeutic target for neurodegenerative disease.

\section{References}

Alam ZI, Jenner A, Daniel SE, Lees AJ, Cairns N, Marsden CD, Jenner P, Halliwell B (1997) Oxidative DNA damage in the parkinsonian brain: an apparent selective increase in 8-hydroxyguanine levels in substantia nigra. J Neurochem 69:1196-1203.

Aleyasin H, Cregan SP, Iyirhiaro G, O’Hare MJ, Callaghan SM, Slack RS, Park DS (2004) Nuclear factor $-\kappa \mathrm{B}$ modulates the p53 response in neurons exposed to DNA damage. J Neurosci 24:2963-2973.

Baratte B, Meijer L, Galaktionov K, Beach D (1992) Screening for antimitotic compounds using the $\mathrm{cdc} 25$ tyrosine phosphatase, an activator of the 
mitosis-inducing p34cdc2/cyclin Bcdc13 protein kinase. Anticancer Res 12:873-880.

Becker EB, Bonni A (2004) Cell cycle regulation of neuronal apoptosis in development and disease. Prog Neurobiol 72:1-25.

Biswas SC, Liu DX, Greene LA (2005) Bim is a direct target of a neuronal E2F-dependent apoptotic pathway. J Neurosci 25:8349-8358.

Busser J, Geldmacher DS, Herrup K (1998) Ectopic cell cycle proteins predict the sites of neuronal cell death in Alzheimer's disease brain. J Neurosci 18:2801-2807.

Chen J, Jin K, Chen M, Pei W, Kawaguchi K, Greenberg DA, Simon RP (1997) Early detection of DNA strand breaks in the brain after transient focal ischemia: implications for the role of DNA damage in apoptosis and neuronal cell death. J Neurochem 69:232-245.

Chen P, Zindy F, Abdala C, Liu F, Li X, Roussel MF, Segil N (2003) Progressive hearing loss in mice lacking the cyclin-dependent kinase inhibitor Ink4d. Nat Cell Biol 5:422-426.

Copani A, Condorelli F, Caruso A, Vancheri C, Sala A, Giuffrida Stella AM, Canonico PL, Nicoletti F, Sortino MA (1999) Mitotic signaling by betaamyloid causes neuronal death. FASEB J 13:2225-2234.

Cotman CW (1998) Apoptosis decision cascades and neuronal degeneration in Alzheimer's disease. Neurobiol Aging 19:S29-S32.

Cui J, Holmes EH, Greene TG, Liu PK (2000) Oxidative DNA damage precedes DNA fragmentation after experimental stroke in rat brain. FASEB J 14:955-967.

Ding XL, Husseman J, Tomashevski A, Nochlin D, Jin LW, Vincent I (2000) The cell cycle Cdc25A tyrosine phosphatase is activated in degenerating postmitotic neurons in Alzheimer's disease. Am J Pathol 157:1983-1990.

Dirnagl U, Iadecola C, Moskowitz MA (1999) Pathobiology of ischaemic stroke: an integrated view. Trends Neurosci 22:391-397.

Enokido Y, Araki T, Tanaka K, Aizawa S, Hatanaka H (1996) Involvement of p53 in DNA strand break-induced apoptosis in postmitotic CNS neurons. Eur J Neurosci 8:1812-1821.

Farinelli SE, Greene LA (1996) Cell cycle blockers mimosine, ciclopirox, and deferoxamine prevent the death of PC12 cells and postmitotic sympathetic neurons after removal of trophic support. J Neurosci 16:1150-1162.

Fortin A, Cregan SP, MacLaurin JG, Kushwaha N, Hickman ES, Thompson CS, Hakim A, Albert PR, Cecconi F, Helin K, Park DS, Slack RS (2001) APAF1 is a key transcriptional target for p53 in the regulation of neuronal cell death. J Cell Biol 155:207-216.

Gabbita SP, Lovell MA, Markesbery WR (1998) Increased nuclear DNA oxidation in the brain in Alzheimer's disease. J Neurochem 71:2034-2040.

Gautier J, Solomon MJ, Booher RN, Bazan JF, Kirschner MW (1991) cdc25 is a specific tyrosine phosphatase that directly activates p34cdc2. Cell 67:197-211.

Giovanni A, Wirtz-Brugger F, Keramaris E, Slack R, Park DS (1999) Involvement of cell cycle elements, cyclin-dependent kinases, pRb, and E2F $\times$ DP, in B-amyloid-induced neuronal death. J Biol Chem 274:19011-19016

Giovanni A, Keramaris E, Morris EJ, Hou ST, O’Hare M, Dyson N, Robertson GS, Slack RS, Park DS (2000) E2F1 mediates death of B-amyloid-treated cortical neurons in a manner independent of $\mathrm{p} 53$ and dependent on Bax and caspase 3. J Biol Chem 275:11553-11560.

Greene LA, Biswas SC, Liu DX (2004) Cell cycle molecules and vertebrate neuron death: E2F at the hub. Cell Death Differ 11:49-60.

Herrup K, Arendt T (2002) Re-expression of cell cycle proteins induces neuronal cell death during Alzheimer's disease. J Alzheimers Dis 4:243-247.

Herrup K, Neve R, Ackerman SL, Copani A (2004) Divide and die: cell cycle events as triggers of nerve cell death. J Neurosci 24:9232-9239.

Hirao A, Cheung A, Duncan G, Girard PM, Elia AJ, Wakeham A, Okada H, Sarkissian T, Wong JA, Sakai T, De Stanchina E, Bristow RG, Suda T, Lowe SW, Jeggo PA, Elledge SJ, Mak TW (2002) Chk2 is a tumor suppressor that regulates apoptosis in both an ataxia telangiectasia mutated (ATM)-dependent and an ATM-independent manner. Mol Cell Biol 22:6521-6532.

Hou ST, Callaghan D, Fournier MC, Hill I, Kang L, Massie B, Morley P, Murray C, Rasquinha I, Slack R, MacManus JP (2000) The transcription factor E2F1 modulates apoptosis of neurons. J Neurochem 75:91-100.

Iavarone A, Massague J (1997) Repression of the CDK activator Cdc25A and cell-cycle arrest by cytokine TGF-beta in cells lacking the CDK inhibitor p15. Nature 387:417-422.
Jenner P (1998) Oxidative mechanisms in nigral cell death in Parkinson's disease. Mov Disord 13 [Suppl 1]:24-34.

Jordan-Sciutto KL, Malaiyandi LM, Bowser R (2002) Altered distribution of cell cycle transcriptional regulators during Alzheimer disease. J Neuropathol Exp Neurol 61:358-367.

Katchanov J, Harms C, Gertz K, Hauck L, Waeber C, Hirt L, Priller J, von Harsdorf R, Bruck W, Hortnagl H, Dirnagl U, Bhide PG, Endres M (2001) Mild cerebral ischemia induces loss of cyclin-dependent kinase inhibitors and activation of cell cycle machinery before delayed neuronal cell death. J Neurosci 21:5045-5053.

Keramaris E, Stefanis L, MacLaurin J, Harada N, Takaku K, Ishikawa T, Taketo MM, Robertson GS, Nicholson DW, Slack RS, Park DS (2000) Involvement of caspase 3 in apoptotic death of cortical neurons evoked by DNA damage. Mol Cell Neurosci 15:368-379.

Keramaris E, Hirao A, Slack RS, Mak TW, Park DS (2003) Ataxia telangiectasia-mutated protein can regulate p53 and neuronal death independent of Chk2 in response to DNA damage. J Biol Chem 278:37782-37789.

Konishi Y, Bonni A (2003) The E2F-Cdc2 cell-cycle pathway specifically mediates activity deprivation-induced apoptosis of postmitotic neurons J Neurosci 23:1649-1658.

Kruman II, Wersto RP, Cardozo-Pelaez F, Smilenov L, Chan SL, Chrest FJ, Emokpae R Jr, Gorospe M, Mattson MP (2004) Cell cycle activation linked to neuronal cell death initiated by DNA damage. Neuron 41:549-561.

Lam MH, Rosen JM (2004) Chk1 versus Cdc25: chking one's levels of cellular proliferation. Cell cycle 3:1355-1357.

Lazo JS, Nemoto K, Pestell KE, Cooley K, Southwick EC, Mitchell DA, Furey W, Gussio R, Zaharevitz DW, Joo B, Wipf P (2002) Identification of a potent and selective pharmacophore for $\mathrm{Cdc} 25$ dual specificity phosphatase inhibitors. Mol Pharmacol 61:720-728.

Li Y, Chopp M, Powers C, Jiang N (1997) Immunoreactivity of cyclin D1/ cdk4 in neurons and oligodendrocytes after focal cerebral ischemia in rat. J Cereb Blood Flow Metab 17:846-856.

Liu DX, Greene LA (2001) Regulation of neuronal survival and death by E2F-dependent gene repression and derepression. Neuron 32:425-438.

Liu LF, Desai SD, Li TK, Mao Y, Sun M, Sim SP (2000) Mechanism of action of camptothecin. Ann NY Acad Sci 922:1-10.

Liu Q, Guntuku S, Cui XS, Matsuoka S, Cortez D, Tamai K, Luo G, CarattiniRivera S, DeMayo F, Bradley A, Donehower LA, Elledge SJ (2000) Chk1 is an essential kinase that is regulated by Atr and required for the $\mathrm{G}(2) / \mathrm{M}$ DNA damage checkpoint. Genes Dev 14:1448-1459.

Lovell MA, Markesbery WR (2001) Ratio of 8-hydroxyguanine in intact DNA to free 8-hydroxyguanine is increased in Alzheimer disease ventricular cerebrospinal fluid. Arch Neurol 58:392-396.

Mailand N, Falck J, Lukas C, Syljuasen RG, Welcker M, Bartek J, Lukas J (2000) Rapid destruction of human Cdc25A in response to DNA damage. Science 288:1425-1429.

Mansfield SH, Castillo M (1994) MR of cis-platinum-induced optic neuritis. AJNR Am J Neuroradiol 15:1178-1180.

Matsushime H, Quelle DE, Shurtleff SA, Shibuya M, Sherr CJ, Kato JY (1994) D-type cyclin-dependent kinase activity in mammalian cells. Mol Cell Biol 14:2066-2076.

McShea A, Harris PL, Webster KR, Wahl AF, Smith MA (1997) Abnormal expression of the cell cycle regulators P16 and CDK4 in Alzheimer's disease. Am J Pathol 150:1933-1939.

Mochizuki T, Kitanaka C, Noguichi K, Muramatsu T, Asai A, Kuchino Y (1999) Physical and functional interactions between Pim-1 kinase and cdc25A phosphatase. Implications for the Pim-1-mediated activation of the c-Myc signaling pathway. J Biol Chem 247:18659-18666.

Morris EJ, Geller HM (1996) Induction of neuronal apoptosis by camptothecin, an inhibitor of DNA topoisomerase-I: evidence for cell cycleindependent toxicity. J Cell Biol 134:757-770.

Morris EJ, Dreixler JC, Cheng KY, Wilson PM, Gin RM, Geller HM (1999) Optimization of single-cell gel electrophoresis (SCGE) for quantitative analysis of neuronal DNA damage. Biotechniques 26:282-283, 286-289.

Morris EJ, Keramaris E, Rideout HJ, Slack RS, Dyson NJ, Stefanis L, Park DS (2001) Cyclin-dependent kinases and P53 pathways are activated independently and mediate Bax activation in neurons after DNA damage. J Neurosci 21:5017-5026.

Nguyen MD, Boudreau M, Kriz J, Couillard-Despres S, Kaplan DR, Julien JP (2003) Cell cycle regulators in the neuronal death pathway of amyotro- 
phic lateral sclerosis caused by mutant superoxide dismutase 1. J Neurosci 23:2131-2140.

O’Hare MJ, Hou ST, Morris EJ, Cregan SP, Xu Q, Slack RS, Park DS (2000) Induction and modulation of cerebellar granule neuron death by E2F-1. J Biol Chem 275:25358-25364.

Olive PL, Banath JP (1993) Induction and rejoining of radiation-induced DNA single-strand breaks: "tail moment" as a function of position in the cell cycle. Mutat Res 294:275-283.

Osuga H, Osuga S, Wang F, Fetni R, Hogan MJ, Slack RS, Hakim AM, Ikeda JE, Park DS (2000) Cyclin-dependent kinases as a therapeutic target for stroke. Proc Natl Acad Sci USA 97:10254-10259.

Padmanabhan J, Park DS, Greene LA, Shelanski ML (1999) Role of cell cycle regulatory proteins in cerebellar granule neuron apoptosis. J Neurosci 19:8747-8756.

Park DS, Farinelli SE, Greene LA (1996) Inhibitors of cyclin-dependent kinases promote survival of post-mitotic neuronally differentiated PC12 cells and sympathetic neurons. J Biol Chem 271:8161-8169.

Park DS, Morris EJ, Greene LA, Geller HM (1997a) G1/S cell cycle blockers and inhibitors of cyclin-dependent kinases suppress camptothecininduced neuronal apoptosis. J Neurosci 17:1256-1270.

Park DS, Levine B, Ferrari G, Greene LA (1997b) Cyclin dependent kinase inhibitors and dominant negative cyclin dependent kinase 4 and 6 promote survival of NGF-deprived sympathetic neurons. J Neurosci 17:8975-8983.

Park DS, Morris EJ, Padmanabhan J, Shelanski ML, Geller HM, Greene LA (1998) Cyclin-dependent kinases participate in death of neurons evoked by DNA-damaging agents. J Cell Biol 143:457-467.

Park DS, Morris EJ, Bremner R, Keramaris E, Padmanabhan J, Rosenbaum M, Shelanski ML, Geller HM, Greene LA (2000) Involvement of retinoblastoma family members and E2F/DP complexes in the death of neurons evoked by DNA damage. J Neurosci 20:3104-3114.

Radcliffe J, Bunin GR, Sutton LN, Goldwein JW, Phillips PC (1994) Cognitive deficits in long-term survivors of childhood medulloblastoma and other noncortical tumors: age-dependent effects of whole brain radiation. Int J Dev Neurosci 12:327-334.

Rashidian J, Iyirhiaro G, Aleyasin H, Rios M, Vincent I, Callaghan S, Bland RJ, Slack RS, During MJ, Park DS (2005) Multiple cyclin-dependent kinases signals are critical mediators of ischemia/hypoxic neuronal death in vitro and in vivo. Proc Natl Acad Sci USA 102:14080-14085.

Rideout HJ, Wang Q, Park DS, Stefanis L (2003) Cyclin-dependent kinase activity is required for apoptotic death but not inclusion formation in cortical neurons after proteasomal inhibition. J Neurosci 23:1237-1245.

Robison SH, Bradley WG (1984) DNA damage and chronic neuronal degenerations. J Neurol Sci 64:11-20.

Rukenstein A, Rydel RE, Greene LA (1991) Multiple agents rescue PC12 cells from serum-free cell death by translation- and transcriptionindependent mechanisms. J Neurosci 11:2552-2563.

Sanchez Y, Wong C, Thoma RS, Richman R, Wu Z, Piwnica-Worms H, Elledge SJ (1997) Conservation of the Chk1 checkpoint pathway in mammals: linkage of DNA damage to Cdk regulation through Cdc25. Science 277:1497-1501.

Smith PD, Crocker SJ, Jackson-Lewis V, Jordan-Sciutto KL, Hayley S, Mount MP, O'Hare MJ, Callaghan S, Slack RS, Przedborski S, Anisman H, Park DS (2003) Cyclin-dependent kinase 5 is a mediator of dopaminergic neuron loss in a mouse model of Parkinson's disease. Proc Natl Acad Sci USA 100:13650-13655.

Smith PD, O’Hare MJ, Park DS (2004) CDKs: taking on a role as mediators of dopaminergic loss in Parkinson's disease. Trends Mol Med 10:445-451.

Smith RA, Walker T, Xie X, Hou ST (2003) Involvement of the transcription factor E2F1/Rb in kainic acid-induced death of murine cerebellar granule cells. Brain Res Mol Brain Res 116:70-79.

Stefanis L, Burke RE, Greene LA (1997) Apoptosis in neurodegenerative disorders. Curr Opin Neurol 10:299-305.

Stefanis L, Park DS, Friedman WJ, Greene LA (1999) Caspase-dependent and -independent death of camptothecin-treated embryonic cortical neurons. J Neurosci 19:6235-6247.

Sumrejkanchanakij P, Tamamori-Adachi M, Matsunaga Y, Eto K, Ikeda MA (2003) Role of cyclin D1 cytoplasmic sequestration in the survival of postmitotic neurons. Oncogene 22:8723-8730.

Takai H, Tominaga K, Motoyama N, Minamishima YA, Nagahama H, Tsukiyama T, Ikeda K, Nakayama K, Nakanishi M (2000) Aberrant cell cycle checkpoint function and early embryonic death in Chk1 $(-/-)$ mice. Genes Dev 14:1439-1447.

Takai H, Naka K, Okada Y, Watanabe M, Harada N, Saito S, Anderson CW, Appella E, Nakanishi M, Suzuki H, Nagashima K, Sawa H, Ikeda K, Motoyama N (2002) Chk2-deficient mice exhibit radioresistance and defective p53-mediated transcription. EMBO J 21:5195-5205.

Terada Y, Tatsuka M, Jinno S, Okayama H (1995) Requirement for tyrosine phosphorylation of Cdk4 in G1 arrest induced by ultraviolet irradiation. Nature 376:358-362.

Tobita M, Nagano I, Nakamura S, Itoyama Y, Kogure K (1995) DNA singlestrand breaks in postischemic gerbil brain detected by in situ nick translation procedure. Neurosci Lett 200:129-132.

Trinh E, Boutillier AL, Loeffler JP (2001) Regulation of the retinoblastomadependent Mdm2 and E2F-1 signaling pathways during neuronal apoptosis. Mol Cell Neurosci 17:342-353.

Vincent I, Bu B, Hudson K, Husseman J, Nochlin D, Jin L (2001) Constitutive Cdc25B tyrosine phosphatase activity in adult brain neurons with M phase-type alterations in Alzheimer's disease. Neuroscience 105:639-650

Wallach PM, Love SR, Fiorica JV, Hoffman MS, Flannery MT (1992) Erythromycin associated hearing loss in a patient with prior cis-platinum induced ototoxicity. J Fla Med Assoc 79:821-822.

Wen Y, Yang S, Liu R, Simpkins JW (2005) Cell-cycle regulators are involved in transient cerebral ischemia induced neuronal apoptosis in female rats. FEBS Lett 579:4591-4599.

Xia Z, Dudek H, Miranti CK, Greenberg ME (1996) Calcium influx via the NMDA receptor induces immediate early gene transcription by a MAP kinase/ERK-dependent mechanism. J Neurosci 16:5425-5436.

Xiang H, Hochman DW, Saya H, Fujiwara T, Schwartzkroin PA, Morrison RS (1996) Evidence for p53-mediated modulation of neuronal viability. J Neurosci 16:6753-6765.

Zindy F, Cunningham JJ, Sherr CJ, Jogal S, Smeyne RJ, Roussel MF (1999) Postnatal neuronal proliferation in mice lacking Ink4d and Kipl inhibitors of cyclin-dependent kinases. Proc Natl Acad Sci USA 96:13462-13467. 